\title{
Low vitamin D-modulated calcium-regulating proteins in psoriasis vulgaris plaques: S100A7 overexpression depends on joint involvement
}

\author{
SUSANA CUBILLOS and JOHANNES NORGAUER \\ Department of Dermatology, Jena University Hospital, D-07743 Jena, Germany \\ Received April 12, 2016; Accepted August 1, 2016
}

DOI: 10.3892/ijmm.2016.2718

\begin{abstract}
Psoriasis is an inflammatory skin disease with or without joint involvement. In this disease, the thickened epidermis and impaired barrier are associated with altered calcium gradients. Calcium and vitamin D are known to play important roles in keratinocyte differentiation and bone metabolism. Intracellular calcium is regulated by calciumsensing receptor (CASR), calcium release-activated calcium modulator (ORAI) and stromal interaction molecule (STIM). Other proteins modulated by vitamin D play important roles in calcium regulation e.g., calbindin 1 (CALB1) and transient receptor potential cation channel 6 (TRPV6). In this study, we aimed to investigate the expression of calcium-regulating proteins in the plaques of patients with psoriasis vulgaris with or without joint inflammation. We confirmed low calcium levels, keratinocyte hyperproliferation and an altered epidermal barrier. The CASR, ORAI1, ORAI3, STIM1, CALB1 and TRPV6 mRNA, as well as the sterol 27-hydroxylase (CYP27A1), 25-hydroxyvitamin $\mathrm{D}_{3}$ 1- $\alpha$-hydroxylase (CYP27B1) and 1,25-dihydroxyvitamin D3 24-hydroxylase (CYP24A1) protein levels were low in the plaques of patients with psoriasis. We demonstrated S100 calcium-binding protein A7 (S100A7) overexpression in the plaques of patients with psoriasis vulgaris with joint inflammation, compared with those without joint involvement. We suggest an altered capacity to regulate the intracellular $\mathrm{Ca}^{2+}$ concentration $\left(\left[\mathrm{Ca}^{2+}\right] \mathrm{i}\right)$, characterized by a reduced expression of CASR, ORAI1, ORAI3, STIM1, CALB1 and TRPV6 associated with diminished levels of 1,25-dihydroxyvitamin $\mathrm{D}_{3}\left[1,25(\mathrm{OH})_{2} \mathrm{D}_{3}\right]$, which may be associated with an altered balance between keratinocyte proliferation and differ-
\end{abstract}

Correspondence to: Ms. Susana Cubillos, Department of Dermatology, Jena University Hospital, Erfurter Strasse 35, D-07743 Jena, Germany

E-mail: s_cubillos@yahoo.com

Abbreviations: HC, healthy controls; PV, psoriasis vulgaris; PVPsA, psoriasis vulgaris with joint inflammation; CE, cornified envelope

Key words: psoriasis vulgaris, joint involvement, calcium regulators, $\mathrm{S} 100$ calcium-binding protein $\mathrm{A} 7$, vitamin D entiation in the psoriatic epidermis. Additionally, differences in S100A7 expression depend on the presence of joint involvement.

\section{Introduction}

The normal epidermal barrier results from an equilibrated differentiation process, in which proliferative undifferentiated keratinocytes move from the basal to the granular layer, turning to a differentiated state of the cornified envelope (CE) (1). Epidermal differentiation involves the expression switch from basal keratin 5 (KRT5) and KRT14 to suprabasal KRT1 and KRT10 (2,3). In addition, structural proteins, such as involucrin (IVL) and periplakin (PPL) are crosslinked with other proteins and serve as substrates for lipids in the CE (4-6). Psoriasis is a common chronic inflammatory skin disease with or without joint involvement. Psoriatic skin lesions are characterized by a thickened epidermis due to increased keratinocyte proliferation, abnormal differentiation and the infiltration of inflammatory cells into the dermis and epidermis. KRT6 and KRT16, markers of abnormal hyperproliferation, are upregulated in psoriatic lesions, whereas KRT1 and KRT10, markers of terminal differentiation, are downregulated (7). Calcium is a major regulator of keratinocyte differentiation. Alterations in calcium levels from 0.03 to $0.1 \mathrm{mM}$ trigger keratinocyte differentiation in vitro (8). In the epidermis, calcium gradients from low levels in the proliferative basal layer to high levels in the differentiated granular layer, have been reported (9). This gradient disappeares after barrier disruption (10) or in psoriasis (11).

In vitro data have demonstrated that the extracellular $\mathrm{Ca}^{2+}$ concentration $\left(\left[\mathrm{Ca}^{2+}\right] \mathrm{o}\right)$ initiates keratinocyte differentiation by increasing the intracellular $\mathrm{Ca}^{2+}$ concentration $\left(\left[\mathrm{Ca}^{2+}\right] \mathrm{i}\right)$. This process is regulated by proteins of the plasma membrane and endoplasmic reticulum, such as the calciumsensing receptor (CASR) $(12,13)$ and store-operated $\mathrm{Ca}^{2+}$ entry (SOCE) proteins (14). It has recently been demonstrated that the two major SOCE components, stromal interaction molecule (STIM) and calcium release-activated calcium modulator (CRAC or ORAI) (15-17) are involved in keratinocyte proliferation and differentiation (18). Moreover, the epidermis is the major source of the calcium homeostasis regulator, vitamin D. Keratinocytes metabolize vitamin D to the active 1,25 -dihydroxyvitamin $\mathrm{D}_{3}\left[1,25(\mathrm{OH})_{2} \mathrm{D}_{3}\right]$ by several cytochrome P450 enzymes (19). This metabolite regulates epidermal proliferation in the basal layer and 
promotes differentiation in the upper layers after binding to the vitamin D receptor (VDR) (20). In addition to CASR (21), other calcium-regulating proteins are modulated by $1,25(\mathrm{OH})_{2} \mathrm{D}_{3}$; e.g., the calcium-binding calbindin 1 (CALB1) is involved in early keratinocyte differentiation (22). Additionally, transient receptor potential subfamily $\mathrm{V}$ member 6 (TRPV6) is a highly selective $\mathrm{Ca}^{2+}$ channel upregulated by $1,25(\mathrm{OH})_{2} \mathrm{D}_{3}(23)$ and is involved in $\mathrm{Ca}^{2+} / 1,25(\mathrm{OH})_{2} \mathrm{D}_{3}$-induced keratinocyte differentiation (24). On the other hand, antimicrobial peptides found in the epidermis, such as S100 calcium-binding protein A7 (S100A7) (25), which bind calcium and zinc (26), are inducible in keratinocytes by differentiation (27), and are highly overexpressed in psoriasis (28).

Currently, the knowledge about the expression of calcium-regulating proteins in the epidermal plaques of psoriasis vulgaris is limited. In this study, we thus aimed to investigate the gene expression of calcium-regulating proteins in the plaques of patients with psoriasis vulgaris with joint inflammation (PVPsA) and without joint inflammation (PV).

\section{Subjects and methods}

Subject characteristics. This study, approved by the Ethics Committee at the Medical Faculty of the Friedrich-Schiller University Jena, Jena, Germany (project 1940-01/07), was conducted according to the principles of the Declaration of Helsinki. Written consent was obtained from all participants prior to enrollment. Patients were diagnosed by dermatologists at the Department of Dermatology of the Jena University Hospital. The presence of joint manifestations was confirmed by power doppler ultrasonography (Esaote, Genoa, Italy) and Rheumascan Xeralite (Mivenion GmbH, Berlin, Germany). Eighteen patients with psoriasis vulgaris and six healthy controls (HC) were included. Seven patients with psoriasis vulgaris had no clinical signs of joint inflammation (PV) and eleven were diagnosed with psoriatic arthritis (PVPsA). The mean age ranges of the patients were as follows: PV group, 45.1 \pm 22.7 ; PVPsA group, 51.9 \pm 14.9 ; and $\mathrm{HC}$ group, 48.7 \pm 9.9 . Patients with other types of psoriasis, skin diseases, allergy, autoimmune diseases, any topical or systemic treatment, including vitamin D supplementation or phototherapy 5 months before or at the time of recruitment, were excluded.

Skin biopsies. One centimeter biopsies were obtained from patient lesional and control skin after local anesthesia. Biopsies were divided into two 5-mm pieces: one was preserved frozen in 'RNA Later' solution for quantitative polymerase chain reaction (PCR) assessment, and the other embedded in paraffin for posterior $5 \mu \mathrm{m}$ thicknesses sectioning and processing with Alizarin Red S staining and immunohistochemistry.

Alizarin Red S staining for calcium deposition. Dewaxed skin section slides were incubated for 2 min with Alizarin Red S solution (Santa Cruz Biotechnology, Inc., Dallas, TX, USA). The slides were mounted in 'DPX mounting medium' (SigmaAldrich, St. Louis, MO, USA) and evaluated under a Zeiss Axio Imager M1 microscope (Carl Zeiss, Jena, Germany).

Quantitative PCR analysis of skin differentiation markers and calcium-regulating proteins. Total RNA was isolated from the skin biopsies using an RNeasy Fibrous Tissue kit (Qiagen, Hilden, Germany) and then reverse transcribed into cDNA using the high capacity RNA-to-cDNA kit (Applied Biosystems, Foster City, CA, USA) according to the manufacturer's instructions. The KRT10, KRT16, IVL, PPL, CASR, ORAI1, ORAI3, STIM1, VDR, CALB1, TRPV6 and S100A7 mRNA levels were quantified using a 7500 TaqMan Real-Time PCR system with human KRT10 (Hs01043114_g1), KRT16 (Hs00955088_g1), IVL (Hs00846307_s1), PPL (Hs00160312_m1), CASR (Hs01047793_m1), ORAI1 (Hs03046013_m1), ORAI3 (Hs00743683_s1), STIM1 (Hs00162394_m1), VDR (Hs00172113_m1), CALB1 (Hs01077197_m1), TRPV6 (Hs01114089_g1), S100A7 (Hs01923188_u1) and GADPH (endogeneous control) TaqMan Gene Expression assays (all from Applied Biosystems). According to the manufacturer's instructions, $50 \mathrm{ng} \mathrm{cDNA} /$ $50 \mu \mathrm{l}$ final volume PCR reaction mix were used under the following conditions: an initial AmpErase Uracil N-glycosylase activation step at $50^{\circ} \mathrm{C}$ for $2 \mathrm{~min}$ followed by $10 \mathrm{~min}$ denaturation at $95^{\circ} \mathrm{C}$, and 40 cycles as follows: $15 \mathrm{sec}$ at $95^{\circ} \mathrm{C}$ and $1 \mathrm{~min}$ at $60^{\circ} \mathrm{C}$. Relative quantification was performed using $\Delta \Delta \mathrm{Ct}$ method, as previously described (29).

Immunohistochemistry of skin biopsies. Dewaxed and rehydrated slides were processed for antigen unmasking. Briefly, the slides were boiled in Tris-EDTA buffer (10 mM Tris Base, $1 \mathrm{mM}$ EDTA, 0.05\% Tween-20, pH 9.0) for $20 \mathrm{~min}$ and then cooled with tap water. The slides were permeabilized for $15 \mathrm{~min}$ and blocked for $30 \mathrm{~min}$ at room temperature. The samples were incubated overnight at $4^{\circ} \mathrm{C}$ with the diluted 1:200 primary antibodies [anti-human KRT10 (sc-51581), KRT16 (sc-53255), IVL (sc-15225), PPL (sc-16754), CASR (sc-32182), ORAI1 (sc-377281), ORAI3 (sc-292104), STIM1 (sc-68897), VDR (sc-1009), CALB1 (sc-365360), TRPV6 (sc-28763), S100A7 (sc-67047), sterol 27-hydroxylase (CYP27A1) (sc-390974), 25-hydroxyvitamin $\mathrm{D}_{3}$ 1- $\alpha$-hydroxylase (CYP27B1) (sc-49643) and 1,25-dihydroxyvitamin $\mathrm{D}_{3}$ 24-hydroxylase (CYP24A1) (sc-66851); all from Santa Cruz Biotechnology, Inc.]. After washing, the slides were incubated $2 \mathrm{~h}$ at room temperature with the 1:400 diluted secondary antibodies [Alexa Fluor 488 (A-21441)-, 594 (A-11058)- and 647 (A-31571)conjugated; Molecular Probes, Eugene, OR, USA]. Additionally, the slides were incubated for 5 min with $2 \mu \mathrm{g} / \mathrm{ml}$ DAPI (Sigma-Aldrich) and observed under a Zeiss Axio Imager M1 microscope (Carl Zeiss).

Statistical analyses. Statistical analyses were performed using GraphPad Prism software (GraphPad Software, La Jolla, CA, USA). Differences between groups were analyzed by the Mann-Whitney or t-test. A value of $\mathrm{P}<0.05$ was considered to indicate a statistically significant difference.

\section{Results}

Low calcium levels in plaques of patients with psoriasis. The normal epidermis is characterized by a calcium gradient which ranges from low levels in the basal layer to high levels in the spinous and granular layers (30). In this study, we performed Alizarin Red S staining, which is usually used to identify 

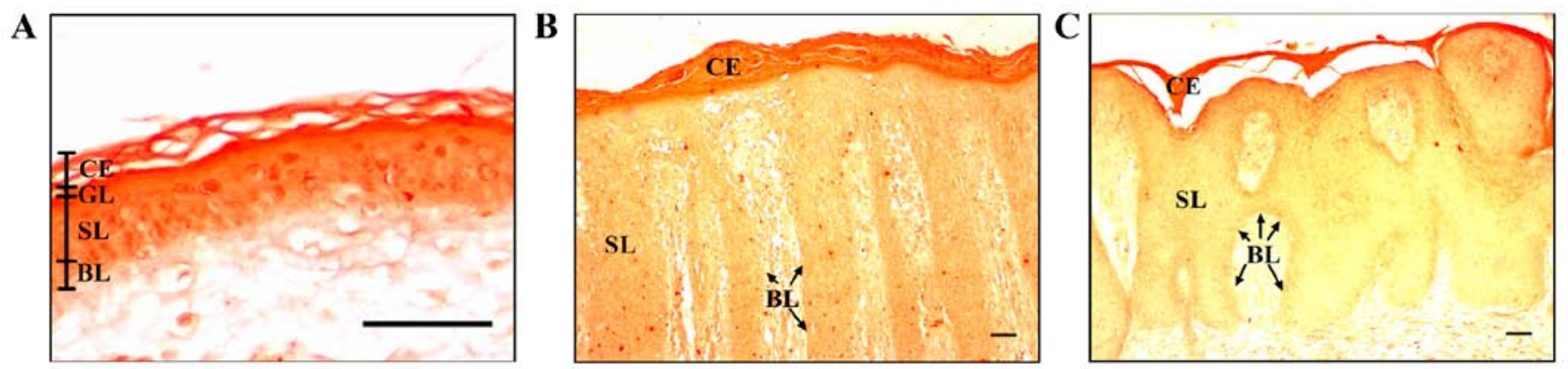

Figure 1. Calcium staining in the plaques of patients with psoriasis vulgaris with or without joint inflammation, and the control epidermis. Light microscopic images of skin sections from (A) healthy controls (HC), and in the plaques of psoriasis vulgaris patients (B) without joint inflammation (PV) and (C) with joint inflammation (PVPsA) were incubated with Alizarin Red S solution. BL, basal layer; SL, spinous layer; GL, granular layer; CE, cornified envelope. Scale bar, $100 \mu \mathrm{m}$.

A

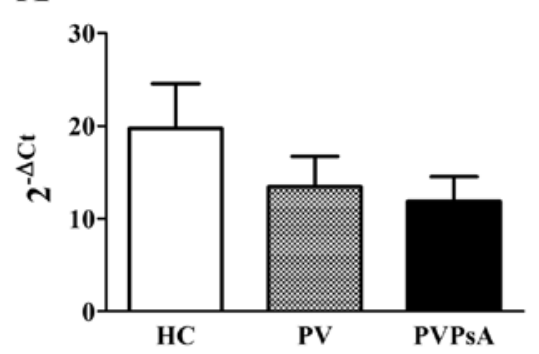

C

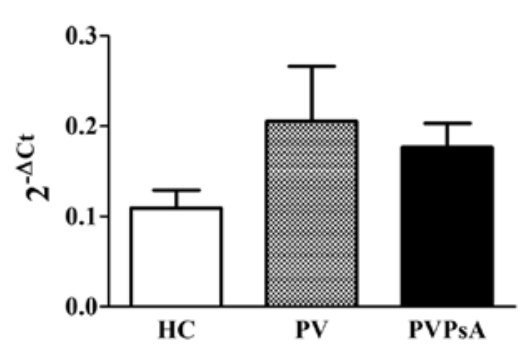

$\mathbf{E}$

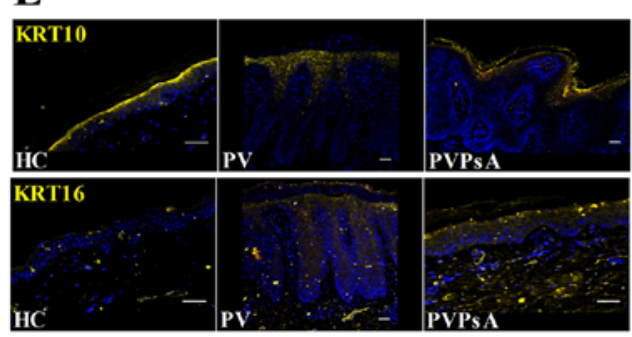

B

KRT16

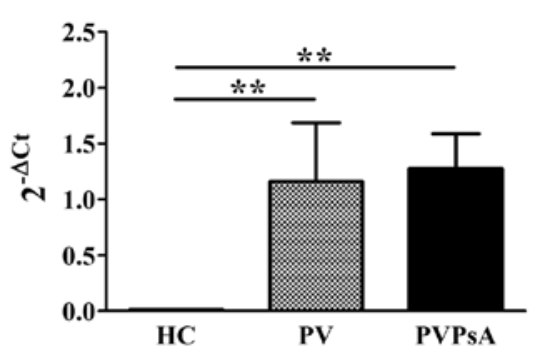

D

PPL
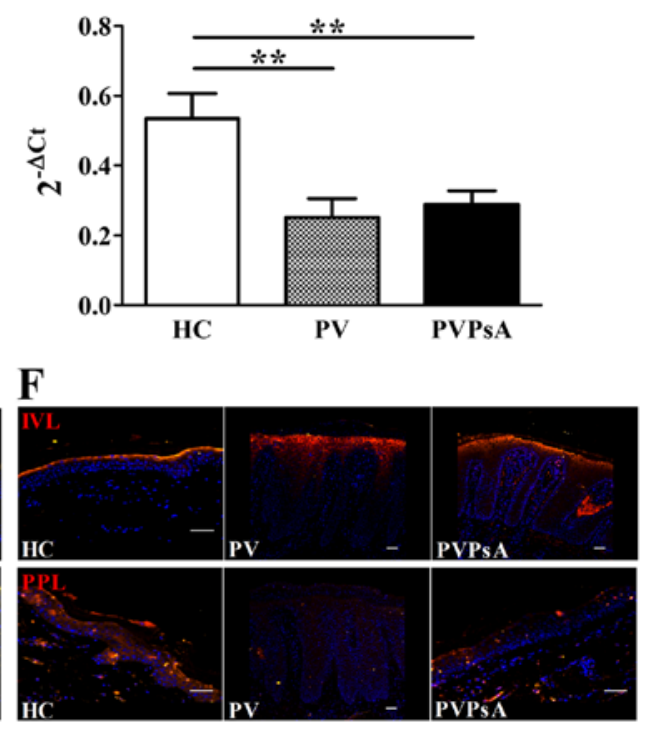

Figure 2. Keratinocyte hyperproliferation and epidermal differentiation markers in patients with psoriasis vulgaris with or without joint inflammation and healthy controls. Quantitative PCR analysis of skin biopsies from healthy controls (HC), and patients with psoriasis vulgaris without joint inflammation (PV) and with joint inflammation (PVPsA). Columns represent the means \pm SEM of $2^{-\Delta C t}$ (x-axes) of (A) keratin 10 (KRT10), (B) KRT16, (C) involucrin (IVL) and (D) periplakin (PPL). HC, n=6; PV, $n=7$; PVPsA, $n=11 .^{* *} \mathrm{P}<0.01$. (E and F) Microscopic images representative of immunofluorescence staining of (E) KRT10 and KRT16, and (F) IVL and PPL, in 5- $\mu$ m-thick skin sections from the HC, PV and PVPsA groups. Scale bar, $100 \mu \mathrm{m}$.

calcium in bone cells and tissue sections, to detect calcium in the skin biopsies. This dye forms an orange-red complex with calcium. We observed lower levels of calcium in the epidermis from the biopsies of patients with psoriasis, as evidenced by the light orange staining in the basal and spinous layers, compared with the dark orange observed in the same layers in the control epidermis (Fig. 1). There were no differences in the staining of the epidermis of the patients with psoriasis vulgaris with or without joint inflammation. Our results confirmed the already reported altered calcium gradient in the epidermis of patients with psoriasis (11).

Keratinocyte hyperproliferation and altered epidermal differentiation in patients with psoriasis. Subsequently, we 
A

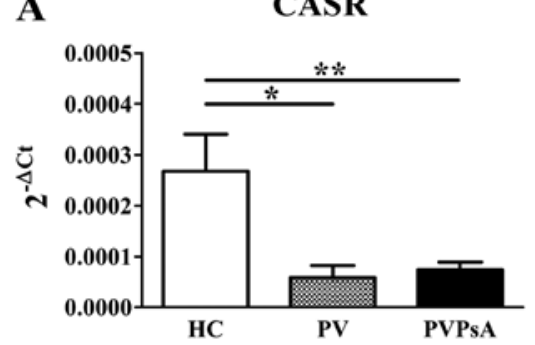

C

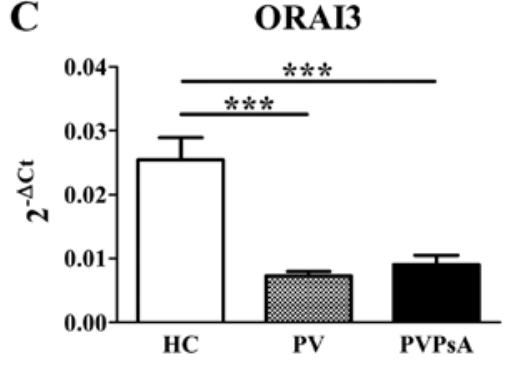

$\mathbf{E}$

VDR

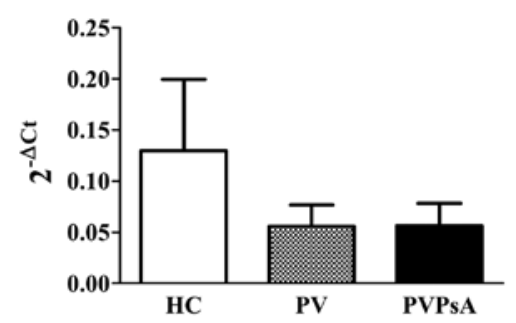

G

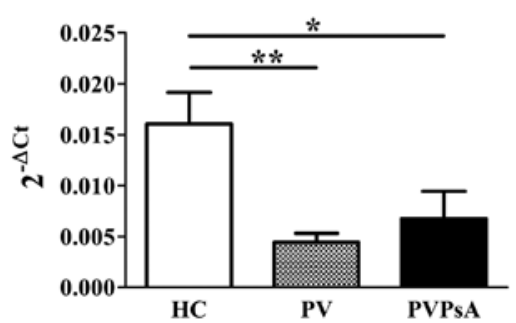

B

ORAI1

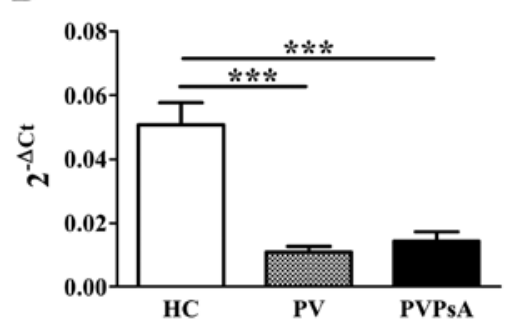

D

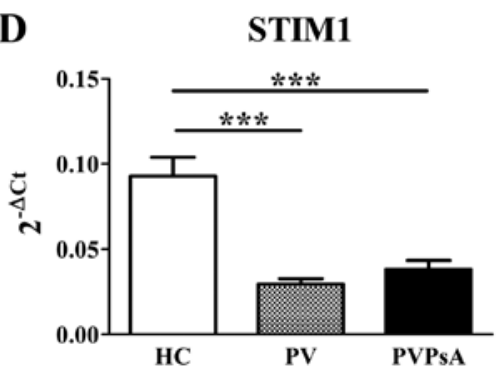

F

CALB1

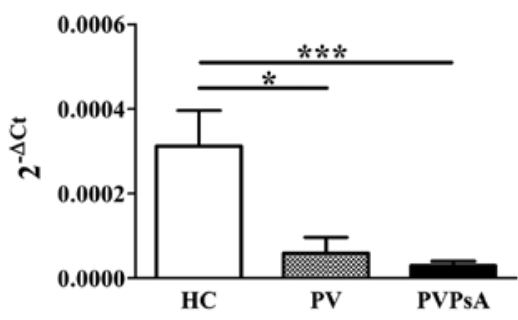

H

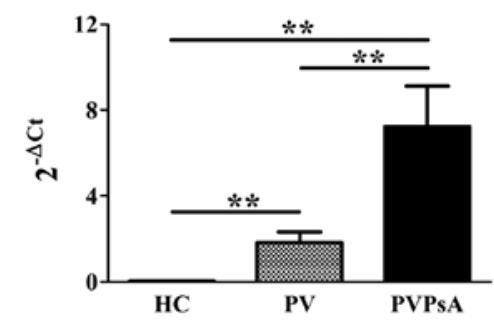

Figure 3. Gene expression of the calcium-modulating proteins, vitamin D receptor (VDR) and S100 calcium-binding protein A7 (S100A7) in plaques of patients with psoriasis vulgaris with or without joint inflammation, and the control epidermis. Quantitative PCR analysis of skin biopsies from healthy controls (HC), and patients with psoriasis vulgaris without joint inflammation $(\mathrm{PV})$ and with joint inflammation (PVPsA). Columns represent the means $\pm \mathrm{SEM}$ of $2^{-\Delta C t}(\mathrm{x}-\mathrm{axes})$ of (A) calcium-sensing receptor (CASR), (B) calcium release-activated channel modulator 1 (ORAI1), (C) ORAI3, (D) stromal interaction molecule 1 (STIM1), (E) VDR, (F) calbindin 1 (CALB1), (G) transient receptor potential cation channel 6 (TRPV6) and (H) S100A7. HC, n=6; PV, n=7; PVPsA, n=11. "P<0.05; ${ }^{* *} \mathrm{P}<0.01 ;{ }^{* * *} \mathrm{P}<0.001$.

assessed the keratinocyte differentiation state by measuring the mRNA expression of keratinocyte differentiation markers in the epidermis from biopsies of patients with PV and PVPsA. as well as in the controls. Our results revealed that the mRNA levels of KRT10, one of the first keratins expressed by keratinocyte differentiation during cornification (31), displayed no statistically significant differences between the PV, PVPsA and control groups ( $\mathrm{P}>0.05$; Fig. 2A). By contrast, KRT16, a marker for keratinocyte hyperproliferation (7), exhibited highly increased mRNA levels in the plaques of patients with psoriasis compared with the controls (98-fold, $\mathrm{P}=0.004$, and 107-fold, $\mathrm{P}=0.001$, respectively; Fig. 2B). The early and late keratinocyte differentiation markers, IVL and PPL, respectively, play important roles in the crosslinking of CE proteins $(32,33)$. We did not find any statistically significant differences in the mRNA levels of IVL between the PV, PVPsA and control groups $(\mathrm{P}>0.05$;
Fig. 2C). However, the PPL mRNA levels were lower in the plaques of patients with PV and PVPsA compared with the controls (2.1-fold, $\mathrm{P}=0.009$, and 1.9 -fold, $\mathrm{P}=0.006$, respectively; Fig. 2D). At the protein level, we observed a similar expression pattern of KRT10 in the upper spinous layer in the biopsy specimens of patients in the PV, PVPsA and control groups. By contrast, KRT16 was expressed mainly in the spinous layer in the plaques of patients with PV and PVPsA, and was almost absent in the control epidermis (Fig. 2E). Furthermore, IVL was expressed in a similar pattern in the upper spinous layer in biopsy specimens of PV, PVPsA and controls, while PPL was expressed in the spinous and granular layers of the control epidermis, and was almost absent in the plaques of patients with PV and PVPsA (Fig. 2F). These results confirmed altered keratinocyte differentiation in the plaques of patients with psoriasis vulgaris. 


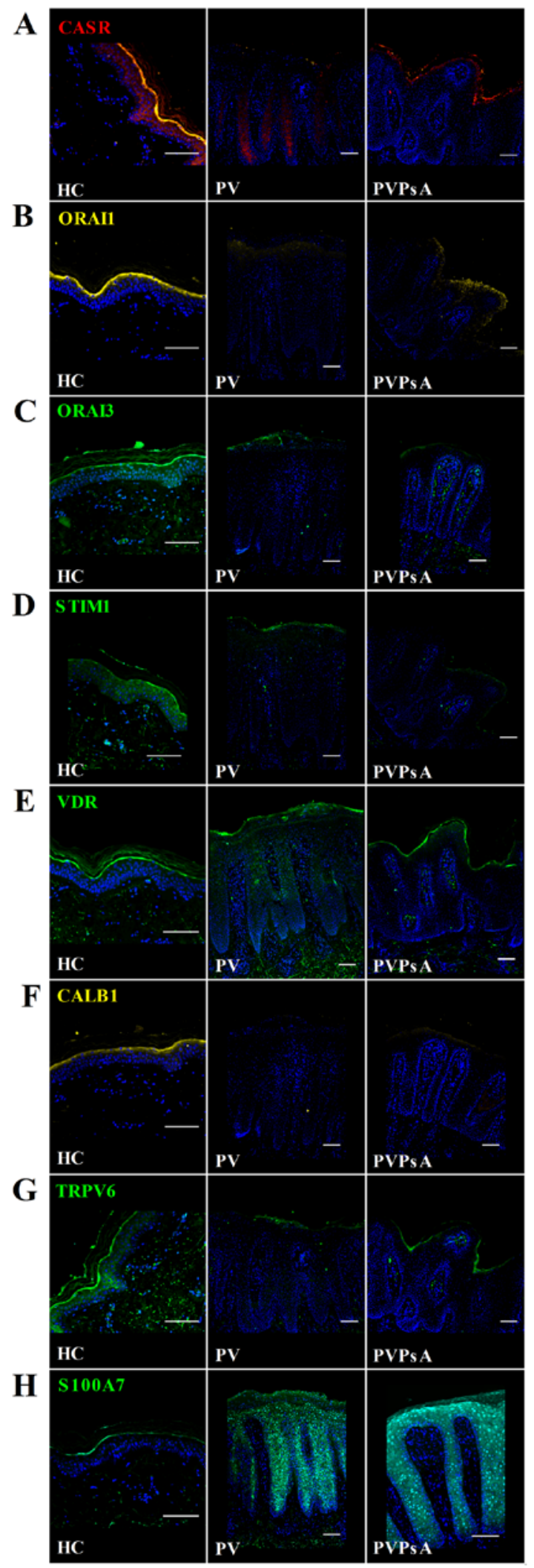

Figure 4. Protein levels of the calcium-modulating proteins, vitamin D receptor (VDR) and S100 calcium-binding protein A7 (S100A7) in plaques of patients with psoriasis vulgaris with or without joint inflammation, and control epidermis. Immunofluorescent microscopic images of skin sections from healthy controls (HC), and patients with psoriasis vulgaris without joint inflammation (PV) and with joint inflammation (PVPsA). Images represent staining of (A) calcium-sensing receptor (CASR), (B) calcium release-activated channel modulator 1 (ORAI1), (C) ORAI3, (D) stromal interaction molecule 1 (STIM1), (E) VDR, (F) calbindin 1 (CALB1), (G) transient receptor potential cation channel 6 (TRPV6) and (H) S100A7. Scale bar, $100 \mu \mathrm{m}$.
Low expression of calcium-regulating proteins and S100A7 overexpression differences in the plaques of patients with psoriasis. $\left[\mathrm{Ca}^{2+}\right]$ o plays a critical role in keratinocyte differentiation (34) and $\left[\mathrm{Ca}^{2+}\right] \mathrm{i}$ is regulated by proteins of the plasma membrane and endoplasmic reticulum (14). Thus, we then evaluated the gene expression of calcium-regulating proteins in the plaques of patients with PV and PVPsA. Our results revealed lower mRNA levels of CASR (4.6-fold, $\mathrm{P}=0.012$; 3.6-fold, $\mathrm{P}=0.004$, respectively), ORAI1 (4.7-fold, $\mathrm{P}<0.0001 ; 3.6$-fold, $\mathrm{P}<0.0001$, respectively), ORAI3 (3.5-fold, $\mathrm{P}<0.0001 ; 2.8$-fold, $\mathrm{P}<0.0001$, respectively) and STIM1 (3.1-fold, $\mathrm{P}<0.0001 ; 2.5$-fold, $\mathrm{P}<0.0001$, respectively) in the plaques of patients with PV and PVPsA compared with the control epidermis (Fig. 3A-D, respectively).

In addition, $1,25(\mathrm{OH})_{2} \mathrm{D}_{3}$ is involved in the regulation of keratinocyte differentiation by calcium through VDR (35). Our results revealed no statistically significant differences in the VDR mRNA levels (Fig. 3E). CALB1 is regulated by $1,25(\mathrm{OH})_{2} \mathrm{D}_{3}$ and is involved in intracellular $\mathrm{Ca}^{2+}$ translocation (36). Our results revealed lower CALB1 mRNA levels in the plaques of patients with PV and PVPsA compared with the control epidermis (5.3-fold, $\mathrm{P}=0.014 ; 10.3$-fold, $\mathrm{P}<0.0001$, respectively; Fig. 3F). In addition, TRPV6 is another protein regulated by $1,25(\mathrm{OH})_{2} \mathrm{D}_{3}$ and is a highly selective $\mathrm{Ca}^{2+}$ channel (23) involved in keratinocyte differentiation (24). Again, our results revealed lower TRPV6 mRNA levels in the plaques of patients with psoriasis compared with the control epidermis (3.6-fold, $\mathrm{P}=0.003$; 2.4 -fold, $\mathrm{P}=0.014$, respectively; Fig. 3G). By contrast, S100A7, another calcium-binding protein, inducible in keratinocytes by differentiation (27) and involved in the epidermal barrier formation (26), is highly overexpressed in psoriasis (28). Our results confirmed those of published studies by showing a much higher S100A7 gene expression in the plaques of patients with PV and PVPsA compared with the controls (61-fold, $\mathrm{P}=0.003$, and 240-fold, $\mathrm{P}=0.003$, respectively). Surprisingly, the $\mathrm{S} 100 \mathrm{~A} 7 \mathrm{mRNA}$ levels were even greater in the plaques of patients also suffering from joint inflammation (PVPsA) compared those of patients without joint inflammation (PV) (3.9-fold, $\mathrm{P}<0.01$; Fig. $3 \mathrm{H}$ ).

Immunohistochemical staining also revealed that the protein levels of CASR, ORAI1, ORAI3 and STIM were lower in the plaques of patients with PV and PVPsA compared with the control epidermis (Fig. 4A-D). Principally, no differences were observed in the VDR expression pattern in the plaques of patients with psoriasis patients and the control epidermis (Fig. 4E). CALB1 and TRPV6 also displayed a lower protein expression in the plaques of patients with psoriasis patients compared with the control epidermis; e.g., CALB1 localized mainly in the granular layer of control epidermis and was almost absent in psoriatic plaques (Fig. 4F); and TRPV6 was expressed in the spinous and granular layers of the control epidermis and in very low levels in the plaques of patients with PV and PVPsA (Fig. 4G). By contrast, S100A7 expression was higher in the psoriatic plaques compared with the control epidermis. S100A7 localized in the whole epidermis of patients with PV and PVPsA compared with the granular layer of the control epidermis (Fig. 4H).

These results suggest an altered keratinocyte response to $\left[\mathrm{Ca}^{2+}\right] \mathrm{o}$ and the regulation of $\left[\mathrm{Ca}^{2+}\right] \mathrm{i}$ in the epidermis of patients with psoriasis. Moreover, the data with S100A7 indicated a 


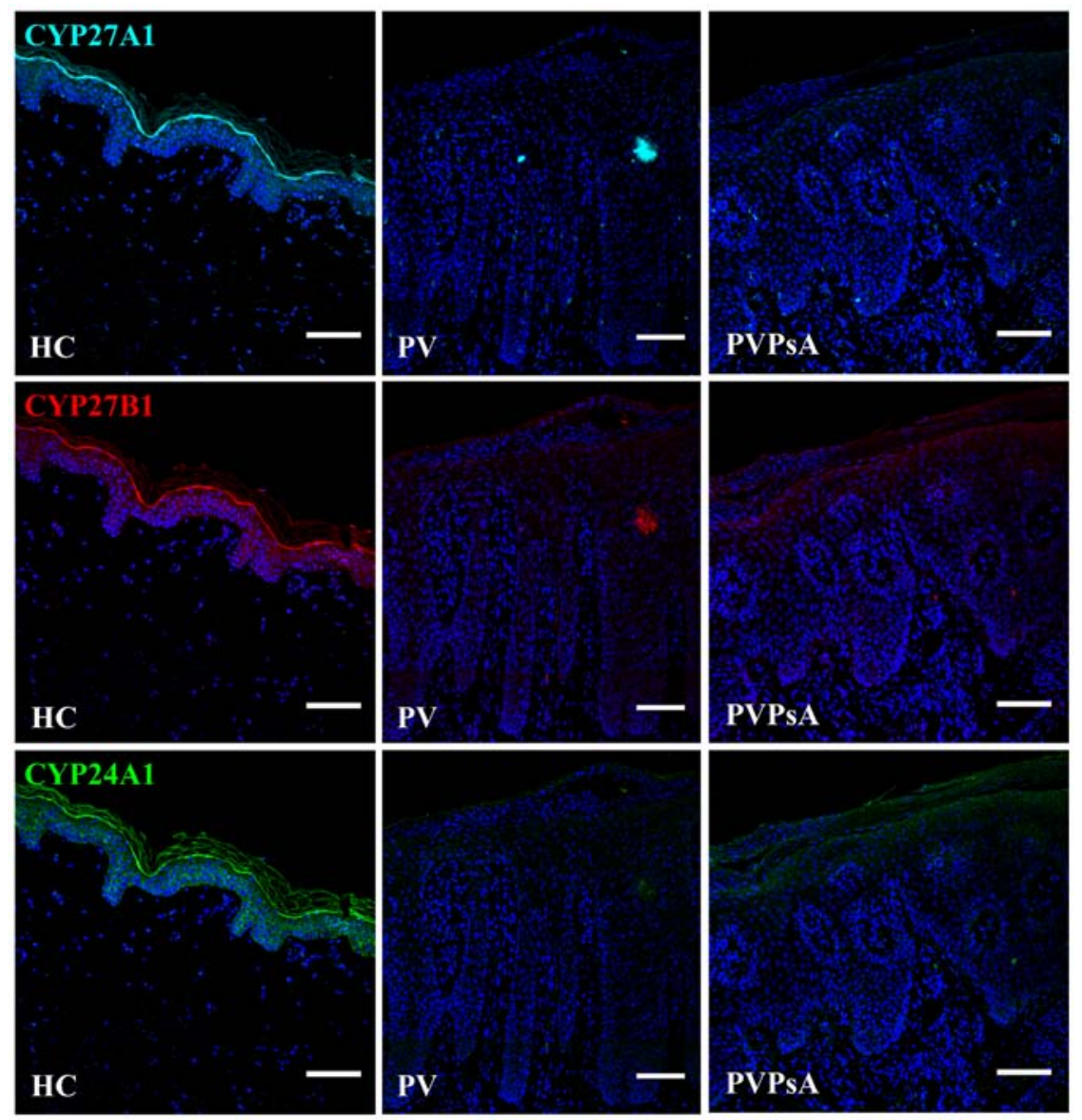

Figure 5. Protein levels of cytochrome $\mathrm{P} 450$ enzymes involved in 1,25-dihydroxyvitamin $\mathrm{D}_{3}\left[1,25(\mathrm{OH})_{2} \mathrm{D}_{3}\right]$ metabolism in plaques of patients with psoriasis vulgaris with or without joint inflammation, and control epidermis. Immunofluorescent microscopic images of skin sections from healthy controls (HC), and patients with psoriasis vulgaris without (PV) and with joint inflammation (PVPsA). Images represent staining of vitamin $\mathrm{D}_{3}$-25-hydroxylase (CYP27A1), 25-OH-D ${ }_{3}$-1 $\alpha$-hydroxylase (CYP27B1), and 25-OH-D ${ }_{3}$-24-hydroxylase (CYP24A1). Scale bar, $100 \mu \mathrm{m}$.

dependence on comorbidity revealed by the mRNA and protein expression differences in the skin of patients with psoriasis vulgaris with or without joint inflammation.

Low protein levels of CYP27A1, CYP27B1 and CYP24A1 in the plaques of patients with psoriasis. The vitamin D active form $1,25(\mathrm{OH})_{2} \mathrm{D}_{3}$ is synthesized by cytochrome $\mathrm{P} 450$ enzymes. First, vitamin $\mathrm{D}_{3}$ is hydroxylated to $25(\mathrm{OH}) \mathrm{D}_{3}$ by CYP27A1 in the liver (37), then CYP27B1 converts $25(\mathrm{OH})$ $\mathrm{D}_{3}$ to $1,25(\mathrm{OH})_{2} \mathrm{D}_{3}$ in the kidneys (38), and CYP24A1 can hydroxylate $1,25(\mathrm{OH})_{2} \mathrm{D}_{3}$, as well as $25(\mathrm{OH}) \mathrm{D}_{3}$, generating metabolically inactive products (39). Additionally, keratinocytes contain these enzymes $(12,40)$. As these enzymes can be considered markers of vitamin D metabolism, and the expression of the calcium-regulating proteins examined in this study is modulated by $1,25(\mathrm{OH})_{2} \mathrm{D}_{3}$, we then examined their protein levels in the plaques of patients with PV and PVPsA. Our results revealed lower protein levels of CYP27A1, CYP27B1 and CYP24A1 in the plaques of patients with PV and PVPsA compared with the control epidermis (Fig. 5).

\section{Discussion}

The beneficial effects of vitamin D induced by exposure to sunlight in the treatment of psoriasis vulgaris have been known for decades. Moreover, the topical application of vitamin D analogs has been used successfully as the first-line treatment for psoriasis vulgaris (41). In this study, we analyzed vitamin D-dependent, as well as calcium-regulating proteins in the plaques of patients with psoriasis vulgaris. The data presented, schematically summarized in Table I, show an altered expression of differentiation markers in the plaques of patients with psoriasis vulgaris. Although no differences in VDR expression were found, the expression of the calciumregulating proteins, CASR, ORAI1, ORAI3, STIM1, CALB1 and TRPV6 was reduced, and by contrast, S100A7 was overexpressed in the plaques of patients with psoriasis vulgaris. In addition, the protein levels of CYP27A1, CYP27B1 and CYP24A1 were reduced in the plaques of these patients. Despite the limitation of the use of whole skin gene expression, the results from immunohistochemical analysis confirmed the epidermal expression of these proteins.

Calcium and vitamin D play important roles in keratinocyte differentiation $(42,43)$. In the normal epidermis, calcium gradients have been reported (9). An increase in $\left[\mathrm{Ca}^{2+}\right] \mathrm{o}$ results in the expression of early differentiation markers (44). Low calcium levels confirmed in the plaques of patients with psoriatic correspond to the high expression of the hyperproliferation marker, KRT16. However, no differences in KRT10 expression, a marker of keratinocyte differentiation, were observed between patients with psoriasis and the controls. The integrity of the epidermal barrier is crucial for the main- 
Table I. Expression overview of proteins involved in keratinocyte proliferation and differentiation, vitamin D-modulated calcium regulators and metabolical enzymes in plaques of patients with psoriasis vulgaris with or without joint inflammation compared with control epidermis.

\begin{tabular}{|c|c|c|c|}
\hline Protein & $\downarrow$ & $\leftrightarrow$ & $\uparrow$ \\
\hline $\begin{array}{l}\text { Keratinocyte } \\
\text { proliferation and } \\
\text { differentiation }\end{array}$ & PPL & $\begin{array}{l}\text { KRT10 } \\
\text { IVL }\end{array}$ & KRT16 \\
\hline $\begin{array}{l}\text { Calcium regulation } \\
\text { and vitamin D }\end{array}$ & $\begin{array}{l}\text { CASR } \\
\text { ORAI1 } \\
\text { ORAI3 } \\
\text { STIM1 } \\
\text { CALB1 } \\
\text { TRPV6 }\end{array}$ & & S100A7 \\
\hline Vitamin D & $\begin{array}{l}\text { CYP27A1 } \\
\text { CYP27B1 } \\
\text { CYP24A1 }\end{array}$ & VDR & \\
\hline
\end{tabular}

KRT, keratin; IVL, involucrin; PPL, periplakin; CASR, calcium-sensing receptor; ORAI1, calcium release-activated channel modulator 1; ORAI3, calcium release-activated channel modulator 3; STIM1, stromal interaction molecule 1; VDR, vitamin D receptor; CALB1, calbindin 1; TRPV6, transient receptor potential cation channel 6; S100A7, S100 calcium-binding protein A7; CYP27A1, vitamin $\mathrm{D}_{3}$-25-hydroxylase; CYP27B1, 25-OH-D $-1 \alpha$-hydroxylase; CYP24A1, 25-OH-D ${ }_{3}$-24-hydroxylase. Arrows indicate lower $(\downarrow)$, no change $(\leftrightarrow)$ or higher $(\uparrow)$ protein expression in plaques of patients with psoriasis compared with control epidermis.

tenance of the epidermal calcium gradient (45). According to de Koning et al (46) our results demonstrated IVL expressed in the granular layer of control epidermis, but extended into the spinous layer in psoriatic plaques, suggesting a disrupted barrier. In addition, we observed reduced PPL levels in plaques of patients with psoriasis corresponding with an impaired epidermal barrier observed in PPL-deficient mice (47).

Intracellular calcium is regulated by an increase in $\mathrm{Ca}^{2+}$ influx through CASR and $\mathrm{Ca}^{2+}$ release from intracellular stores, followed by $\mathrm{Ca}^{2+}$ re-uptake through SOCE proteins $(14,48)$. CASR is required for normal keratinocyte differentiation (49). The overexpression of CASR accelerates epidermal differentiation, hair follicle formation and permeability (50). while its inactivation or deletion inhibits calcium-induced keratinocyte differentiation by reducing $\mathrm{Ca}^{2+}$ intracellular stores, and disrupts epidermal $\mathrm{Ca}^{2+}$ gradient and permeability $(48,51,52,53)$. Our results revealed a low CASR expression in the plaques of patients with psoriasis vulgaris, suggesting an altered capacity to regulate $\left[\mathrm{Ca}^{2+}\right]$ o influx. ORAI and STIM form clusters and co-localize with each other to enable $\mathrm{Ca}^{2+}$ influx and release from intracellular stores (54). The knockdown or inhibition of ORAI1 and/or STIM1 alters $\mathrm{Ca}^{2+}$ storage and decreases the differentiation and migration of undifferentiated keratinocytes (18). ORAI3 forms heteromultimeric channel complexes with ORAI1 and STIM1, and mutated ORAI1 is sufficient to exert a negative effect on the other CRAC members (55). In this study, we observed a low expression of ORAI1, ORAI3 and STIM1 in the plaques of patients with psoriasis, suggesting that keratinocytes in these patients have an altered capacity to regulate $\left[\mathrm{Ca}^{2+}\right]$ i levels.

$1,25(\mathrm{OH})_{2} \mathrm{D}_{3}$ increases keratinocyte differentiation by increasing $\left[\mathrm{Ca}^{2+}\right] \mathrm{i}$ levels (35). The loss of VDR or the loss of the capacity to produce $1,25(\mathrm{OH})_{2} \mathrm{D}_{3}$ disrupts epidermal differentiation, resulting in keratinocyte hyperproliferation $(56,57)$. In this study, we did not observe any differences in the expression of VDR. However, the levels of CASR, CALB1 and TRPV6 vitamin D-regulated proteins $(58,59)$, essential in $\mathrm{Ca}^{2+} / 1,25(\mathrm{OH})_{2} \mathrm{D}_{3}$-induced differentiation of human keratinocytes $(22,24)$, were reduced in the plaques of patients with psoriasis vulgaris. Other TRP family channels have been shown to be involved in keratinocyte differentiation (60) and complexes with ORAI and STIM have been implicated in the regulation of $\left[\mathrm{Ca}^{2+}\right] \mathrm{i}$ (61). However, only TRPC subfamily members have been investigated in altered $\mathrm{Ca}^{2+}$ influx in psoriatic keratinocytes in response to high $\left[\mathrm{Ca}^{2+}\right]$ o (62).

The binding from $1,25(\mathrm{OH})_{2} \mathrm{D}_{3}$ to VDR and heterodimerization with retinoid $X$ receptors affects the expression of genes that have vitamin $\mathrm{D}$ responsive elements in their promoters (63). The expression of genes such as CASR, CALB1, TRPV6 and STIM1 is regulated by $1,25(\mathrm{OH})_{2} \mathrm{D}_{3}$. In addition, $1,25(\mathrm{OH})_{2} \mathrm{D}_{3}$ is a potent regulator of the $\mathrm{NF}-\kappa \mathrm{B}$ transcription factor (64), which controls ORAI1 and STIM1 expression (65), and modulates SOCE (66). In accordance with the study by Ala-Houhala et al (67), our results revealed lower protein levels of CYP27A1, CYP27B1 and additionally of CYP24A1 in the plaques of patients with psoriasis compared with the control epidermis. The expression of CYP27A1 and CYP27B1 is downregulated by $1,25(\mathrm{OH})_{2} \mathrm{D}_{3}(12,68)$, and the expression of CYP24A1 is induced by $1,25(\mathrm{OH})_{2} \mathrm{D}_{3}(69,70)$, suggesting that low levels of $1,25(\mathrm{OH})_{2} \mathrm{D}_{3}$ are possibly associated with the low calcium-regulating protein levels observed. However, upstream alterations in vitamin D metabolism, e.g., cholesterol metabolism cannot be ruled out. In addition to vitamin $\mathrm{D}_{3}, \mathrm{CYP} 27 \mathrm{~A} 1$ can hydroxylate cholesterol (71). Elevated cholesterol levels in psoriatic lesioned skin is essential for IL-17A signaling and results in the suppression of genes of cholesterol and fatty acid biosynthesis (72).

$1,25(\mathrm{OH})_{2} \mathrm{D}_{3}$ has been shown to exert anti-proliferative effects on keratinocytes (73). Moreover, $1,25(\mathrm{OH})_{2} \mathrm{D}_{3}$ and analogs reduce $\mathrm{S} 100 \mathrm{~A} 7$ levels in the reconstituted human epidermis stimulated by IL-22 (74), in IL-17-stimulated keratinocytes and in skin of patients with psoriasis (75). Apart from its chemotactic and immunomodulatory functions (76), S100A7, a calcium-binding protein, crosslinks with $\mathrm{CE}$ proteins during the terminal stages of keratinocyte differentiation mediated by calcium (77), and is upregulated after epidermal barrier disruption (78) and in psoriatic plaques $(28,79)$. Our results confirmed S100A7 overexpression in the plaques of patients with psoriasis vulgaris, and provide interesting evidence of a higher S100A7 expression in the plaques of patients with PVPsA compared with PV. Bone homeostasis depends on a balance between osteoclasts and osteoblasts. Disordered circulating mediators of bone remodelling (80), and an increased number of circulating osteoclast precursors have been reported in patients with psoriatic arthritis (81). Serum levels of S100A7 are increased in 
patients with psoriasis (28). S100A7 has been shown to enhance osteoclast formation in vitro (82). Moreover, a S100A7 single nucleotide polymorphism has been shown to be associated with psoriatic arthritis (83).

In conclusion, the altered balance between keratinocyte proliferation and differentiation, together with the altered epidermal barrier observed in psoriatic plaques may be associated with an altered capacity to respond to $\left[\mathrm{Ca}^{2+}\right] \mathrm{o}$ and to regulate $\left[\mathrm{Ca}^{2+}\right] \mathrm{i}$, related with a reduced expression of vitamin D-dependent and calcium-regulating proteins, such as CASR, ORAI1, ORAI3, STIM1, CALB1 and TRPV6, as well as with a decreased $1,25(\mathrm{OH})_{2} \mathrm{D}_{3}$ synthesis. However, further studies are required to assess the mechanisms involved. In addition, we demonstrated S100A7 overexpression in the plaques of patients with PVPsA compared with PV, suggesting a dependence on the presence of joint inflammation. These data provide new insight into vitamin D-dependent calcium regulation in psoriasis and also reinforce the importance of vitamin D and light therapy in patients with psoriasis with joint inflammation.

\section{Acknowledgements}

We would like to thank the Departments of Dermatology and Women from the Jena University Hospital for their help in collecting skin biopsies and data from patients with psoriasis and healthy controls. We would also like to thank the Experimental Dermatology III and Histopathology groups and the Institute of Anatomy II. This study was supported by the University Hospital of Jena.

\section{References}

1. Candi E, Schmidt R and Melino G: The cornified envelope: a model of cell death in the skin. Nat Rev Mol Cell Biol 6: 328-340, 2005.

2. Eichner R, Sun TT and Aebi U: The role of keratin subfamilies and keratin pairs in the formation of human epidermal intermediate filaments. J Cell Biol 102: 1767-1777, 1986.

3. Fuchs $\mathrm{E}$ and Green $\mathrm{H}$ : Changes in keratin gene expression during terminal differentiation of the keratinocyte. Cell 19 1033-1042, 1980.

4. Marekov LN and Steinert PM: Ceramides are bound to structural proteins of the human foreskin epidermal cornified cell envelope. J Biol Chem 273: 17763-17770, 1998.

5. Steinert PM and Marekov LN: The proteins elafin, filaggrin, keratin intermediate filaments, loricrin, and small proline-rich proteins 1 and 2 are isodipeptide cross-linked components of the human epidermal cornified cell envelope. J Biol Chem 270: 17702-17711, 1995.

6. Steven AC and Steinert PM: Protein composition of cornified cell envelopes of epidermal keratinocytes. J Cell Sci 107: 693-700, 1994.

7. McKay IA and Leigh IM: Altered keratinocyte growth and differentiation in psoriasis. Clin Dermatol 13: 105-114, 1995.

8. Hennings H, Michael D, Cheng C, Steinert P, Holbrook K and Yuspa SH: Calcium regulation of growth and differentiation of mouse epidermal cells in culture. Cell 19: 245-254, 1980.

9. Menon GK, Grayson S and Elias PM: Ionic calcium reservoirs in mammalian epidermis: ultrastructural localization by ion-capture cytochemistry. J Invest Dermatol 84: 508-512, 1985.

10. Mauro T, Bench G, Sidderas-Haddad E, Feingold K, Elias P and Cullander C: Acute barrier perturbation abolishes the $\mathrm{Ca}^{2+}$ and $\mathrm{K}^{+}$gradients in murine epidermis: quantitative measurement using PIXE. J Invest Dermatol 111: 1198-1201, 1998.

11. Menon GK and Elias PM: Ultrastructural localization of calcium in psoriatic and normal human epidermis. Arch Dermatol 127: 57-63, 1991.

12. Bikle DD, Nemanic MK, Gee E and Elias P: 1,25-Dihydroxyvitamin $\mathrm{D}_{3}$ production by human keratinocytes. Kinetics and regulation. J Clin Invest 78: 557-566, 1986.
13. Tu CL, Oda Y and Bikle DD: Effects of a calcium receptor activator on the cellular response to calcium in human keratinocytes. J Invest Dermatol 113: 340-345, 1999.

14. Lewis RS: The molecular choreography of a store-operated calcium channel. Nature 446: 284-287, 2007.

15. Liou J, Kim ML, Heo WD, Jones JT, Myers JW, Ferrell JE Jr and Meyer T: STIM is a $\mathrm{Ca}^{2+}$ sensor essential for $\mathrm{Ca}^{2+}$-store-depletion-triggered $\mathrm{Ca}^{2+}$ influx. Curr Biol 15: 1235-1241, 2005.

16. Roos J, DiGregorio PJ, Yeromin AV, Ohlsen K, Lioudyno M, Zhang S, Safrina O, Kozak JA, Wagner SL, Cahalan MD, et al: STIM1, an essential and conserved component of store-operated $\mathrm{Ca}^{2+}$ channel function. J Cell Biol 169: 435-445, 2005.

17. Vig M, Peinelt C, Beck A, Koomoa DL, Rabah D, Koblan-Huberson M, Kraft S, Turner H, Fleig A, Penner R and Kinet JP: CRACM1 is a plasma membrane protein essential for store-operated $\mathrm{Ca}^{2+}$ entry. Science 312: 1220-1223, 2006.

18. Numaga-Tomita T and Putney JW: Role of STIM1- and Orail-mediated $\mathrm{Ca}^{2+}$ entry in $\mathrm{Ca}^{2+}$-induced epidermal keratinocyte differentiation. J Cell Sci 126: 605-612, 2013.

19. Jones G, Prosser DE and Kaufmann M: Cytochrome P450-mediated metabolism of vitamin D. J Lipid Res 55: 13-31, 2014.

20. Bikle DD, Tu CL, Xie Z and Oda Y: Vitamin D regulated keratinocyte differentiation: role of coactivators. J Cell Biochem 88: 290-295, 2003.

21. Ratnam AV, Bikle DD and Cho JK: 1,25 Dihydroxyvitamin $\mathrm{D}_{3}$ enhances the calcium response of keratinocytes. J Cell Physiol 178: 188-196, 1999.

22. Rizk-Rabin M and Pavlovitch JH: Epidermal calcium-binding protein: a marker of early differentiation of basal layer keratinocytes of rats. Cell Tissue Res 272: 161-168, 1993.

23. Hoenderop JG, van der Kemp AW, Urben CM, Strugnell SA and Bindels RJ: Effects of vitamin D compounds on renal and intestinal $\mathrm{Ca}^{2+}$ transport proteins in 25-hydroxyvitamin $\mathrm{D}_{3}-1$ alpha-hydroxylase knockout mice. Kidney Int 66 : 1082-1089, 2004.

24. Lehen'kyi V, Beck B, Polakowska R, Charveron M, Bordat P, Skryma R and Prevarskaya N: TRPV6 is a $\mathrm{Ca}^{2+}$ entry channel essential for $\mathrm{Ca}^{2+}$-induced differentiation of human keratinocytes. J Biol Chem 282: 22582-22591, 2007.

25. Schröder JM and Harder J: Antimicrobial skin peptides and proteins. Cell Mol Life Sci 63: 469-486, 2006.

26. Eckert RL, Broome AM, Ruse M, Robinson N, Ryan D and Lee K: S100 proteins in the epidermis. J Invest Dermatol 123: 23-33, 2004.

27. Martinsson H, Yhr M and Enerbäck C: Expression patterns of S100A7 (psoriasin) and S100A9 (calgranulin-B) in keratinocyte differentiation. Exp Dermatol 14: 161-168, 2005.

28. Madsen P, Rasmussen HH, Leffers H, Honoré B, Dejgaard K, Olsen E, Kiil J, Walbum E, Andersen AH, Basse B, et al: Molecular cloning, occurrence, and expression of a novel partially secreted protein 'psoriasin' that is highly up-regulated in psoriatic skin. J Invest Dermatol 97: 701-712, 1991.

29. Livak KJ and Schmittgen TD: Analysis of relative gene expression data using real-time quantitative PCR and the 2(-Delta Delta C(T)) method. Methods 25: 402-408, 2001.

30. Pillai S, Menon GK, Bikle DD and Elias PM: Localization and quantitation of calcium pools and calcium binding sites in cultured human keratinocytes. J Cell Physiol 154: 101-112, 1993.

31. Weiss RA, Eichner R and Sun TT: Monoclonal antibody analysis of keratin expression in epidermal diseases: a 48- and 56-kdalton keratin as molecular markers for hyperproliferative keratinocytes. J Cell Biol 98: 1397-1406, 1984.

32. Robinson NA, LaCelle PT and Eckert RL: Involucrin is a covalently crosslinked constituent of highly purified epidermal corneocytes: evidence for a common pattern of involucrin crosslinking in vivo and in vitro. J Invest Dermatol 107: 101-107, 1996.

33. Ruhrberg C, Hajibagheri MA, Parry DA and Watt FM: Periplakin, a novel component of cornified envelopes and desmosomes that belongs to the plakin family and forms complexes with envoplakin. J Cell Biol 139: 1835-1849, 1997.

34. Eckert RL: Structure, function, and differentiation of the keratinocyte. Physiol Rev 69: 1316-1346, 1989.

35. Bikle DD, Gee E and Pillai S: Regulation of keratinocyte growth, differentiation, and vitamin $\mathrm{D}$ metabolism by analogs of 1,25-dihydroxyvitamin D. J Invest Dermatol 101: 713-718, 1993.

36. Feher JJ: Facilitated calcium diffusion by intestinal calcium-binding protein. Am J Physiol 244: C303-C307, 1983. 
37. Cali JJ and Russell DW: Characterization of human sterol 27-hydroxylase. A mitochondrial cytochrome P-450 that catalyzes multiple oxidation reaction in bile acid biosynthesis. J Biol Chem 266: 7774-7778, 1991.

38. Gray RW, Omdahl JL, Ghazarian JG and DeLuca HF: 25-Hydroxycholecalciferol-1-hydroxylase. Subcellular location and properties. J Biol Chem 247: 7528-7532, 1972

39. Ebert R, Schütze N, Adamski J and Jakob F: Vitamin D signaling is modulated on multiple levels in health and disease. Mol Cell Endocrinol 248: 149-159, 2006.

40. Lehmann $\mathrm{B}$ : The vitamin $\mathrm{D}_{3}$ pathway in human skin and its role for regulation of biological processes. Photochem Photobiol 81 1246-1251, 2005.

41. Soleymani T, Hung T and Soung J: The role of vitamin D in psoriasis: a review. Int J Dermatol 54: 383-392, 2015.

42. Jones KT and Sharpe GR: Intracellular free calcium and growth changes in single human keratinocytes in response to vitamin D and five 20-epi-analogues. Arch Dermatol Res 286: 123-129, 1994.

43. Su MJ, Bikle DD, Mancianti ML and Pillai S: 1,25-Dihydroxyvitamin $D_{3}$ potentiates the keratinocyte response to calcium. J Biol Chem 269: 14723-14729, 1994.

44. Bikle DD, Ratnam A, Mauro T, Harris J and Pillai S: Changes in calcium responsiveness and handling during keratinocyte differentiation. Potential role of the calcium receptor. J Clin Invest 97 1085-1093, 1996.

45. Menon GK, Elias PM and Feingold KR: Integrity of the permeability barrier is crucial for maintenance of the epidermal calcium gradient. Br J Dermatol 130: 139-147, 1994

46. de Koning HD, van den Bogaard EH, Bergboer JG, Kamsteeg M, van Vlijmen-Willems IM, Hitomi K, Henry J, Simon M, Takashita N, Ishida-Yamamoto A, et al: Expression profile of cornified envelope structural proteins and keratinocyte differentiation-regulating proteins during skin barrier repair. $\mathrm{Br}$ J Dermatol 166: 1245-1254, 2012.

47. Sevilla LM, Nachat R, Groot KR, Klement JF, Uitto J, Djian P, Määttä A and Watt FM: Mice deficient in involucrin, envoplakin, and periplakin have a defective epidermal barrier. J Cell Biol 179: $1599-1612,2007$.

48. Tu CL, Chang W and Bikle DD: The role of the calcium sensing receptor in regulating intracellular calcium handling in human epidermal keratinocytes. J Invest Dermatol 127: 1074-1083, 2007.

49. Komuves L, Oda Y, Tu CL, Chang WH, Ho-Pao CL, Mauro T and Bikle DD: Epidermal expression of the full-length extracellular calcium-sensing receptor is required for normal keratinocyte differentiation. J Cell Physiol 192: 45-54, 2002.

50. Turksen K and Troy TC: Overexpression of the calcium sensing receptor accelerates epidermal differentiation and permeability barrier formation in vivo. Mech Dev 120: 733-744, 2003.

51. Tu CL, Oda Y, Komuves L and Bikle DD: The role of the calcium-sensing receptor in epidermal differentiation. Cell Calcium 35: 265-273, 2004

52. Tu CL, Chang W, Xie Z and Bikle DD: Inactivation of the calcium sensing receptor inhibits E-cadherin-mediated cell-cell adhesion and calcium-induced differentiation in human epidermal keratinocytes. J Biol Chem 283: 3519-3528, 2008.

53. Tu CL, Crumrine DA, Man MQ, Chang W, Elalieh H, You M, Elias PM and Bikle DD: Ablation of the calcium-sensing receptor in keratinocytes impairs epidermal differentiation and barrier function. J Invest Dermatol 132: 2350-2359, 2012.

54. Luik RM, Wu MM, Buchanan J and Lewis RS: The elementary unit of store-operated $\mathrm{Ca}^{2+}$ entry: local activation of CRAC channels by STIM1 at ER-plasma membrane junctions. J Cell Biol 174: 815-825, 2006.

55. Lis A, Peinelt C, Beck A, Parvez S, Monteilh-Zoller M, Fleig A and Penner R: CRACM1, CRACM2, and CRACM3 are store-operated $\mathrm{Ca}^{2+}$ channels with distinct functional properties. Curr Biol 17: 794-800, 2007.

56. Bikle DD, Chang S, Crumrine D, Elalieh H, Man MQ, Choi EH, Dardenne O, Xie Z, Arnaud RS, Feingold K and Elias PM: 25 Hydroxyvitamin $D 1$ alpha-hydroxylase is required for optimal epidermal differentiation and permeability barrier homeostasis. J Invest Dermatol 122: 984-992, 2004.

57. Xie Z, Komuves L, Yu QC, Elalieh H, Ng DC, Leary C, Chang S, Crumrine D, Yoshizawa T, Kato S and Bikle DD: Lack of the vitamin $\mathrm{D}$ receptor is associated with reduced epidermal differentiation and hair follicle growth. J Invest Dermatol 118: 11-16, 2002.
58. Gill RK and Christakos S: Identification of sequence elements in mouse calbindin-D28k gene that confer 1,25-dihydroxyvitamin $\mathrm{D}_{3}$ - and butyrate-inducible responses. Proc Natl Acad Sci USA 90: 2984-2988, 1993.

59. Weber K, Erben RG, Rump A and Adamski J: Gene structure and regulation of the murine epithelial calcium channels $\mathrm{ECaC} 1$ and 2. Biochem Biophys Res Commun 289: 1287-1294, 2001

60. Wu LJ, Sweet TB and Clapham DE: International Union of Basic and Clinical Pharmacology. LXXVI. Current progress in the mammalian TRP ion channel family. Pharmacol Rev 62: 381-404, 2010

61. Saul S, Stanisz H, Backes CS, Schwarz EC and Hoth M: How ORAI and TRP channels interfere with each other: interaction models and examples from the immune system and the skin. Eur J Pharmacol 739: 49-59, 2014.

62. Leuner K, Kraus M, Woelfle U, Beschmann H, Harteneck C, Boehncke WH, Schempp CM and Müller WE: Reduced TRPC channel expression in psoriatic keratinocytes is associated with impaired differentiation and enhanced proliferation. PLoS One 6: e14716, 2011

63. Christakos S, Dhawan P, Liu Y, Peng X and Porta A: New insights into the mechanisms of vitamin D action. J Cell Biochem 88: 695-705, 2003.

64. Deb DK, Chen Y, Zhang Z, Zhang Y, Szeto FL, Wong KE, Kong J and Li YC: 1,25-Dihydroxyvitamin $\mathrm{D}_{3}$ suppresses high glucoseinduced angiotensinogen expression in kidney cells by blocking the NF-\{kappa\}B pathway. Am J Physiol Renal Physiol 296: F1212-F1218, 2009.

65. Eylenstein A, Schmidt S, Gu S, Yang W, Schmid E, Schmidt EM, Alesutan I, Szteyn K, Regel I, Shumilina E and Lang F: Transcription factor NF- $\mathrm{KB}$ regulates expression of pore-forming $\mathrm{Ca}^{2+}$ channel unit, Orail, and its activator, STIM1, to control $\mathrm{Ca}^{2+}$ entry and affect cellular functions. J Biol Chem 287: 2719-2730, 2012.

66. Borst O, Münzer P, Schmid E, Schmidt EM, Russo A, Walker B, Yang W, Leibrock C, Szteyn K, Schmidt S, et al: 1,25(OH) vitamin $\mathrm{D}_{3}$-dependent inhibition of platelet $\mathrm{Ca}^{2+}$ signaling and thrombus formation in klotho-deficient mice. FASEB J 28: 2108-2119, 2014

67. Ala-Houhala MJ, Karppinen T, Vähävihu K, Kautiainen H, Dombrowski Y, Snellman E, Schauber J and Reunala T: Narrow-band ultraviolet B treatment boosts serum 25-hydroxyvitamin D in patients with psoriasis on oral vitamin D supplementation. Acta Derm Venereol 94: 146-151, 2014.

68. Holick MF: Resurrection of vitamin D deficiency and rickets. J Clin Invest 116: 2062-2072, 2006.

69. Kerry DM, Dwivedi PP, Hahn CN, Morris HA, Omdahl JL and May BK: Transcriptional synergism between vitamin D-responsive elements in the rat 25-hydroxyvitamin $\mathrm{D}_{3}$ 24-hydroxylase (CYP24) promoter. J Biol Chem 271: 29715-29721, 1996.

70. Lehmann B, Tiebel $O$ and Meurer M: Expression of vitamin $D_{3}$ 25-hydroxylase (CYP27) mRNA after induction by vitamin $\mathrm{D}_{3}$ or UVB radiation in keratinocytes of human skin equivalents - a preliminary study. Arch Dermatol Res 291: 507-510, 1999.

71. Okuda KI: Liver mitochondrial P450 involved in cholesterol catabolism and vitamin D activation. J Lipid Res 35: 361-372, 1994.

72. Varshney P, Narasimhan A, Mittal S, Malik G, Sardana K and Saini N: Transcriptome profiling unveils the role of cholesterol in IL-17A signaling in psoriasis. Sci Rep 6: 19295, 2016.

73. Matsumoto K, Hashimoto K, Nishida Y, Hashiro $M$ and Yoshikawa K: Growth-inhibitory effects of 1,25-dihydroxyvitamin $\mathrm{D}_{3}$ on normal human keratinocytes cultured in serum-free medium. Biochem Biophys Res Commun 166: 916-923, 1990

74. Datta Mitra A, Raychaudhuri SP, Abria CJ, Mitra A, Wright R, Ray R and Kundu-Raychaudhuri S: 1 $\alpha, 25$-Dihydroxyvitamin - $\mathrm{D}_{3}$-3-bromoacetate regulates AKT/mTOR signaling cascades: a therapeutic agent for psoriasis. J Invest Dermatol 133: $1556-1564,2013$

75. HegyiZ,ZwickerS,BureikD,Peric M,Koglin S,Batycka-Baran A, Prinz JC, Ruzicka T, Schauber J and Wolf R: Vitamin D analog calcipotriol suppresses the Th17 cytokine-induced proinflammatory S100 'alarmins' psoriasin (S100A7) and koebnerisin (S100A15) in psoriasis. J Invest Dermatol 132: 1416-1424, 2012.

76. Jinquan T, Vorum H, Larsen CG, Madsen P, Rasmussen HH, Gesser B, Etzerodt M, Honoré B, Celis JE and Thestrup-Pedersen K: Psoriasin: a novel chemotactic protein. J Invest Dermatol 107: 5-10, 1996. 
77. Hoffmann HJ, Olsen E, Etzerodt M, Madsen P, Thøgersen HC, Kruse T and Celis JE: Psoriasin binds calcium and is upregulated by calcium to levels that resemble those observed in normal skin. J Invest Dermatol 103: 370-375, 1994.

78. de Koning HD, Kamsteeg M, Rodijk-Olthuis D van Vlijmen Willems IM, van Erp PE, Schalkwijk J and Zeeuwen PL: Epidermal expression of host response genes upon skin barrier disruption in normal skin and uninvolved skin of psoriasis and atopic dermatitis patients. J Invest Dermatol 131: 263-266, 2011.

79. Harder J, Dressel S, Wittersheim M, Cordes J, Meyer-Hoffert U, Mrowietz U, Fölster-Holst R, Proksch E, Schröder JM, Schwarz T, et al: Enhanced expression and secretion of antimicrobial peptides in atopic dermatitis and after superficial skin injury. J Invest Dermatol 130: 1355-1364, 2010.

80. Dalbeth N, Pool B, Smith T, Callon KE, Lobo M, Taylor WJ, Jones PB, Cornish J and McQueen FM: Circulating mediators of bone remodeling in psoriatic arthritis: implications for disordered osteoclastogenesis and bone erosion. Arthritis Res Ther 12: R164, 2010.
81. Ritchlin CT, Haas-Smith SA, Li P, Hicks DG and Schwarz EM: Mechanisms of TNF-alpha- and RANKL-mediated osteoclastogenesis and bone resorption in psoriatic arthritis. J Clin Invest 111: 821-831, 2003.

82. Paruchuri V, Prasad A, McHugh K, Bhat HK, Polyak K and Ganju RK: S100A7-downregulation inhibits epidermal growth factor-induced signaling in breast cancer cells and blocks osteoclast formation. PLoS One 3: e1741, 2008.

83. Cubillos S, Jaradat SW, Walther M, Truta-Feles K, Koehler MJ and Norgauer J: Association of S100A7 gene polymorphisms with manifestations of common types of psoriasis: effect on serum calcium levels. Exp Dermatol 24: 894-896, 2015. 